\title{
Denver II: evaluation of the development of children treated in the outpatient clinic of Project Einstein in the Community of Paraisópolis
}

\author{
Teste de Denver II: avaliação do desenvolvimento de crianças atendidas no ambulatório do \\ Projeto Einstein na Comunidade de Paraisópolis
}

\author{
Márcia Wanderley de Moraes ${ }^{1}$, Ana Paula Rodrigues Weber ${ }^{2}$, Marcela de Castro e Oliveira Santos ${ }^{3}$, \\ Fabiane de Amorim Almeida ${ }^{4}$
}

\begin{abstract}
Objectives: To evaluate the neuropsychomotor development of children treated in an outpatient clinic, using the Denver Developmental Screening Test II (DDST-R). Methods: This was an exploratory descriptive research using a quantitative approach, conducted in the outpatient clinic of the Project Einstein in the Community of Paraisopolis (PECP), São Paulo, Brazil. The sample consisted of 35 children, from birth to 6 years of age, most of them from 1 to 3 years old $(19 ; 54.3 \%)$. They underwent the Denver II Test, which assesses four neuropsychomotor development areas: gross motor, fine motor adaptive, language and personal-social. Results: Most of the children $(24,68.6 \%)$ had test results compatible with normal development, while $10(28.6 \%)$ had a "risk" test and 1 (2.9\%) was "untestable" due to refusal to carry out the proposed activities. As to the items evaluated in each area, 7 children (20\%) showed a developmental "delay" (when the child does not perform the activity passed by more than $90 \%$ of the children of his/her age) and $18(51 \%)$ required "attention" (when the child does not perform the activity passed by 75 to $90 \%$ of the children of his/her age), predominantly in the language area. Conclusions: Although most of the children (68.6\%) presented normal development in the test, we point out that in the remaining children $(31.4 \%)$, the number of items classified as "delay" or "attention", and tests classified as "risk" or "untestable" suggest impairment in neuropsychomotor development. We underscore the importance of the routine administration of the DDST-R for an early detection of developmental disabilities and thus establish primary prevention programs.
\end{abstract}

Keywords: Child development; Primary health care; Developmental disabilities

\section{RESUMO}

Objetivo: Avaliar o desenvolvimento neuropsicomotor de crianças atendidas em um ambulatório, utilizando o Teste de Triagem de Desenvolvimento de Denver II (TTDD-R). Métodos: Pesquisa descritiva exploratória, com abordagem quantitativa, realizada no ambulatório do Projeto Einstein na Comunidade de Paraisópolis (PECP), em São Paulo. $A$ amostra constituiu-se de 35 crianças, de 0 a 6 anos de idade, sendo que a maioria tinha entre 1 e 3 anos (19;54,3\%). Elas foram submetidas ao Teste de Denver II, que avalia quatro áreas do desenvolvimento neuropsicomotor: motor-grosseiro, motor fino-adaptativo, linguagem e pessoal-social. Resultados: A maioria das crianças (24; 68,6\%) apresentou teste compatível com desenvolvimento normal, enquanto $10(28,6 \%)$ apresentaram teste "de risco" e 1 (2,9\%), resultado "nãotestável", devido às recusas em realizar as atividades propostas. Quanto aos itens avaliados em cada área, 7 crianças $(20 \%)$ apresentaram "atrasos" (quando a criança não executa atividade já realizada por mais de $90 \%$ das crianças com a mesma idade) e 18 (51\%) apresentaram "cuidados" (quando a criança não executa atividade que já é feita por 75 a 90\% das crianças de sua idade), com predomínio na área da linguagem. Conclusões: Embora a maioria das crianças (68,6\%) tenha apresentado desenvolvimento normal no teste, ressalta-se que, nas demais $(31,4 \%)$, o número de itens com "atrasos" ou "cuidados", assim como de testes de "risco" e "não-testável" sugerem prejuízo no desenvolvimento neuropsicomotor. Enfatiza-se a importância da aplicação cotidiana do TTDD-R em ambulatórios, visando detectar precocemente áreas de desenvolvimento com deficiência para estabelecer programas de prevenção primária.

Descritores: Desenvolvimento infantil; Atenção primária à saúde; Deficiências do desenvolvimento

\footnotetext{
Study carried out at Project Einstein in the Community of Paraisopolis (PECP) of the Sociedade Beneficente Israelita Brasileira Albert Einstein - SBIBAE, São Paulo (SP), Brazil.

'Master's degree in Nursing; Professor at Faculdade de Enfermagem of Hospital Israelita Albert Einstein - HIAE, São Paulo (SP), Brazil.

${ }^{2}$ Nurse; Specialist in Pediatric and Neonatal Nursing at Faculdade de Enfermagem of Hospital Israelita Albert Einstein - HIAE, São Paulo (SP), Brazil.

${ }^{3}$ Nurse; Specialist in Pediatric and Neonatal Nursing at Faculdade de Enfermagem of Hospital Israelita Albert Einstein - HIAE, São Paulo (SP), Brazil.

${ }^{4} \mathrm{PhD}$ in Psychology; Professor at Faculdade de Enfermagem of Hospital Israelita Albert Einstein - HIAE, São Paulo (SP), Brazil.

Corresponding author: Márcia Wanderley de Moraes - Rua General Góis Monteiro, 18, apto 212 - Pompeia - CEP $05029-000$ - São Paulo (SP), Brasil - Tel.: 1136755369 - e-mail: marciawander@einstein.br

Received on Feb 12, 2010 - Accepted on May 10, 2010
} 


\section{INTRODUCTION}

In abroaderconcept, the child developmentisunderstood as a process that starts during the intrauterine life and involves several aspects, such as physical growth, neurological maturation, and the construction of skills related to the behavior in the child's cognitive, social and affective domains. The child development involves the individual's ability to carry out increasingly complex functions and is influenced by several factors, thus being worthy of special attention from health and education professionals $^{(1-3)}$.

Children from developing countries are exposed to some risks such as a high prevalence of diseases, being born of a high-risk and/or incomplete pregnancy, and living in adverse socioeconomic conditions, and these make them more likely to present growth and developmental delays ${ }^{(4-5)}$. Studies show the influence of family income, birth weight and nutritional status on the occurrence of developmental delay in children ${ }^{(4,6)}$.

The task of identifying and following up children vulnerable to neuropsychomotor development delay confronts the complexity of the factors that lead to this delay, the inexistence of an efficient surveillance system, the failure to use adequate assessment tools for screening, and more ${ }^{(7)}$.

In an attempt to follow up the neuropsychomotor development of children from birth to six years of age, the Denver Developmental Screening Test (DDTT) was created. Designed by Frankenburg et al. in 1967, this is an instrument for the early detection of disorders of child development that assesses four areas/categories: the gross motor, fine motor adaptive, language and personal-social areas ${ }^{(1,8-12)}$.

The motor behavior is associated with the maturation of the nervous system, corresponding to the control of motor acquisitions. The language behavior encompasses sound and image perceptions as well as their responses, whereas the adaptive behavior consists of the child's reactions to objects and situations. The personal-social behavior, in turn, corresponds to the evaluation of behavior in face of cultural stimuli(1,8-10).

In 1990, the authors proposed a new version, known as Revised Denver Developmental Screening Test (DDST-R) or Denver II. Some language-related items were excluded and other items, which were difficult to administer or interpret, were modified or excluded. The test now consists of 125 items, and the manner of interpreting and administering the tasks and the test as a whole were also modified ${ }^{(1,4,9-10,12-13)}$.

We should point out that this instrument is not a test for the assessment of intelligence and development quotients, but it allows the assessment of the child's current maturational development status, and should not be used as a diagnostic tool ${ }^{(8,11)}$.
The data obtained by means of this test indicate whether the child is developing according to the expected for their chronological age and maturity, and provide information both for planning action strategies for the child and for advising parents ${ }^{(1,4,8-10)}$.

Among the tests used for the follow-up of child development, DDST-R is one of the most widely used, according to a bibliographic survey carried out in the past 25 years that analyzed 174 scientific articles ${ }^{(12)}$.

In the field of pediatric Nursing, this test is used as an effective strategy for collecting data on a child; these data are essential for the elaboration of nurse prescriptions, aiming at the integral care of both the child and their family(8).

For being easy to use, DDST-R may be administered in basic health units, outpatient clinics, medical offices, clinics, in-hospital pediatric units, day-care centers, kindergartens, and services specialized in child development disorders. It allows each professional to read the data obtained in light of their specific background ${ }^{(8)}$.

The administration of DDST-R in pediatric outpatient clinics is of the utmost importance, since it is a primary care service aimed at promoting health, and thus contributes to the early detection of neuropsychomotor development deficits. In view of these facts, the objective of this study was to address the use of this instrument in the follow-up of the development of children treated in an outpatient clinic that cares for children of a slum in São Paulo, Brazil.

\section{OBJECTIVE}

To evaluate the neuropsychomotor development of children from birth to six years of age treated in an outpatient clinic, using the Denver Developmental Screening Test II (DDST-R).

\section{METHODS}

This is an exploratory descriptive study using a quantitative approach, conducted in the outpatient clinic of Project Einstein in the Community of Paraisopolis (PECP), located in the city of São Paulo.

Approximately 10 thousand children aged up to 10 years are treated in this clinic, where they receive free medical and hospital services, advice regarding use of the medications supplied, and multiple complementary initiatives in the health $\operatorname{area}^{(14)}$.

A total of 35 children from birth to six years of age regularly enrolled and treated in PECP participated in the study, with permission of their guardians who gave written informed consent. Most of the children were aged between 12 and 36 months $(19 ; 54.3 \%)$ as shown in table 1. 
Table 1. Distribution of children submitted to the DDST-R per stage of development

\begin{tabular}{lcc}
\hline Stage of development & \multicolumn{2}{c}{ Children } \\
\cline { 2 - 3 } & $\mathbf{n}$ & $\%$ \\
\hline Infant $^{*}$ & 5 & 14.3 \\
Toddler* $^{* *}$ & 19 & 54.3 \\
Pre-school** & 11 & 31.4 \\
\hline Total & 35 & 100 \\
\hline
\end{tabular}

*Infant: children aged up to 12 months;

**Toddler: children aged from one to three years:

***Pre-school: children aged from three to six years.

Data collection occurred after approval of the research project by the Scientific Commission of the Nursing School of Hospital Israelita Albert Einstein and by the institutional Research Ethics Committee (CAAE: 0160.0.028.000-08); authorization was also obtained from the administration of the outpatient clinic where the data were collected.

The data were collected in the second semester of 2008, by means of DDST-R administration, and the materials used were: a red woolen pompom with a thread; a rattle with a narrow handle; raisins; a small bell; ten $2.5-\mathrm{cm}^{3}$ colored wooden blocks; a clear pot with narrow opening; a tennis ball; a red pencil; a small plastic doll with a toy baby bottle; a plastic mug with handles and blank paper ${ }^{(1)}$.

Data were quantitatively analyzed using descriptive statistics, and expressed as absolute numbers and percentages, in the format of tables, considering the criteria of test result interpretation.

Each DDST-R item is correlated with the age and percentage of the standard population that performed one given item or behavior. Each of the items evaluated is classified as:

- normal: when the child performs an activity expected for their age or does not perform an activity passed by less than $75 \%$ of the children of the same age;

- attention: when the child does not perform or refuses to perform an activity passed by 75 to $90 \%$ of the children of the same age;

- delay: when the child does not perform or refuses to perform an activity passed by more than $90 \%$ of the children of the same age ${ }^{(1,8-10,13)}$.

According to the interpretation of the items, the test can be classified as: normal, when the child has no developmental "delay", or requires attention, at most; risk, when the child's test has two or more items classified as requiring attention and/or one or more items showing developmental "delay"; and untestable, when the child "refuses" to perform the activity of one or more items with the age line completely to the right (i.e., activity passed by almost all children) or of more than one item with the age line in the area where 75 to $90 \%$ of the children pass that item ${ }^{(1,10,13)}$.

\section{RESULTS}

The development of the majority of the children assessed $(24 ; 68.5 \%)$ was compatible with their age range; the tests of 10 children $(28.6 \%)$ was classified as "risk", and only $1(2.9 \%)$ was "untestable".

Initially considering the number of children with "delays", in a total of seven, we verified that these delays were more frequent in the "fine motor adaptive" category $(3 ; 42 \%)$, followed by the "personal-social" (2; $28.6 \%)$ and "language" $(2 ; 28.6 \%)$ categories. As for the number of delays identified, in a total of 10 , half (5; $50 \%$ ) occurred in the language area (Table 2).

Table 2. Number of children presenting "delay" and items detected as "delay" in application of the DDST-R, per area/category of the test*

\begin{tabular}{lcccc}
\hline \multirow{2}{*}{ Areas/ categories } & \multicolumn{2}{c}{$\begin{array}{c}\text { Children presenting } \\
\text { "delay" }\end{array}$} & $\begin{array}{c}\text { Test items identified as } \\
\text { "delay" }\end{array}$ \\
\cline { 2 - 5 } & $\mathbf{n}$ & $\%$ & $\mathbf{n}$ & $\%$ \\
\hline Personal-social & 2 & 28.6 & 2 & 20 \\
Fine motor adaptative & 3 & 42.9 & 3 & 30 \\
Language & 2 & 28.6 & 5 & 50
\end{tabular}

\begin{tabular}{lcccc} 
Gross motor & - & - & - & - \\
\hline Total & 7 & 100 & 10 & 100 \\
\hline
\end{tabular}

*Delay occurs when the child does not perform or refuses to perform an activity that is conducted by over $90 \%$ of children at the same age.

As regards the activities classified as requiring "attention", in a total of 21 identified in 18 children, we verified that the language area was also the most frequently affected, both in relation to the number of children $(7 ; 38.9 \%)$, and to the number of test items $(9$; $42.9 \%$ ), as shown in table 3 .

Table 3. Number of children presenting "attention" and items detected as "attention" in application of the DDST-R, per area/category of the test ${ }^{*}$

\begin{tabular}{lcccc}
\hline \multirow{2}{*}{ Areas/ categories } & \multicolumn{2}{c}{$\begin{array}{c}\text { Children presenting } \\
\text { "attention" }\end{array}$} & $\begin{array}{c}\text { Test items identified as } \\
\text { "attention" }\end{array}$ \\
\cline { 2 - 5 } & $\mathbf{n}$ & $\%$ & $\mathbf{n}$ & $\%$ \\
\hline Personal-social & 6 & 33.3 & 7 & 33.3 \\
Fine motor adaptative & 5 & 27.8 & 5 & 23.8 \\
Language & 7 & 38.9 & 9 & 42.9 \\
Gross motor & - & - & - & - \\
\hline Total & 18 & 100 & 21 & 100 \\
\hline
\end{tabular}

*Attention occurs when the child does not perform or refuses to perform an activity that is conducted by 75 to $90 \%$ of children at the same age.

In relation to the only child $(2.9 \%)$ who refused to perform some items of the test, we observed a slight predominance in items of the language area $(2 ; 50 \%)$, as shown in table 4. 
Table 4. Number of children presenting "refusal" in application of the DDST-R, per area/category of the test*

\begin{tabular}{lcc}
\hline Areas/categories & \multicolumn{2}{c}{ Children presenting "refusal" } \\
\cline { 2 - 3 } & $\mathbf{n}$ & $\%$ \\
\hline Personal-social & - & - \\
Fine motor adaptative & 1 & 25 \\
Language & 2 & 50 \\
Gross motor & 1 & 25 \\
Total & 4 & 100 \\
\hline
\end{tabular}

*Refusal occurs when the child refuses to perform an activity in one or more items conducted by over $90 \%$ of children at the same age, or in more than one item that 75 to $90 \%$ of children at the same age have already carried out.

\section{DISCUSSION}

The number of "delays" and tests defined as of "risk" among the assessed children corroborates the findings of previous studies as regards the cumulative effects of multiple risk factors that increase the probability of impaired child development ${ }^{(15-16)}$.

Children from underdeveloped countries concentrate the vast majority of the possible causes that lead to developmental delays. We should point out that this study was conducted in the community of the second largest slum in the State of São Paulo. However, other variables such as maternal education, family size and father's job were not analyzed in the present study, but are also important predictors of the future development of the child ${ }^{(7)}$.

Since the objective of outpatient clinics is to provide the population with primary care, encompassing different specialties of the health area, the routine administration of DDST-R would facilitate the follow-up of possible deficits found in the neuropsychomotor development of children, thus permitting the elaboration of intervention programs aimed at preventing disorders.

Based on the analysis of the results found in relation to "risk" tests or "untestable" children, we recommended that the DDST-R be repeated, preferably two weeks later, for a better assessment of the child.

In relation to the higher frequency of "delays" and "attention" in the language area, two studies conducted with children in day-care centers also showed the persistence of deficits in this domain, that become more prominent after three years of age. According to the authors, these results can be explained, among other factors, by the neurophysiological immaturity for language acquisition and mastering, and also by social stimuli, which are essential for linguistic patterns to develop ${ }^{(13,17)}$.

Considering this situation, it is important to advise parents on the need to follow up their children's activities and stimulate their verbalization using strategies such as: speaking slowly and articulately, singing songs, reading children's stories, etc.

If "risk" tests persist, referral of the child to a specialized professional (speech therapist, psychologist,
ENT physician, and others) should be considered as recommended in the literature ${ }^{(4)}$, in order to identify other factors such as hearing loss or emotional problems that could be related to this insufficient performance.

\section{CONCLUSIONS}

In view of the results, we concluded that the majority of the children showed normal development; $1 / 4$ had a "risk" test, and only 1 child was "untestable". The highest number of items pointing to "delays" or "attention" among the activities performed by the children occurred in the language area.

Considering the number of children with "delays" or "attention", the language area had a high prevalence of "attention" items, whereas more children showed "delays" in the fine motor adaptive area.

\section{REFERENCES}

1. Almeida FA. Desenvolvimento da criança. In: Farah OGD, Sá AC, organizadores. Psicologia aplicada à enfermagem. São Paulo: Manole; 2008.

2. Miranda $L P$, Resegue $R$, Figueiras ACM. A criança e 0 adolescente com problemas do desenvolvimento no ambulatório de pediatria. J Pediatr (Rio J). 2003;79(Supl 1):S33-S42.

3. Marcondes E, Vaz FAC, Ramos JLA, Okay Y. Pediatria básica: pediatria geral e neonatal. 9a ed. São Paulo: Sarvier; 2002.

4. Biscegli TS, Polis LB, Santos LM, Vicentin M. Avaliação do estado nutricional e do desenvolvimento neuropsicomotor em crianças freqüentadoras de creche. Rev Paul Pediatr. 2007;25(4):337-42.

5. Halpern R, Giugliani ERJ, Victora CG, Barros FC, Horta BL. Fatores de risco para suspeita de atraso no desenvolvimento neuropsicomotor aos 12 meses de vida. Rev Chil Pediatr. 2002;73(5):529-39.

6. Halpern R, Barros ADJ, Matijasevich A, Santos IS, Victora CG, Barros FC. Estado de desenvolvimento aos 12 meses de idade de acordo com peso ao nascer e renda familiar: uma comparação de duas coortes de nascimentos no Brasil. Rep Public Health. 2008;24(Supl 3):S444-S450.

7. HalpernR,BarrosFC,HortaBL, VictoraCG. Desenvolvimentoneuropsicomotoraos 12 mesesdeidadeemumacoortedebasepopulacionalnosuldoBrasil:diferenciais conforme peso ao nascer e renda familiar. Rep Public Health. 1996;12(Supl.1): 73:8.

8. Brêtas JRS, Silva MGB, Silva CV. A aplicação do teste de triagem do desenvolvimento de Denver pelo enfermeiro pediatra: relato de caso. Acta Paul. Enferm. 1995; 8(4):9-18.

9. Barness LA. Manual de diagnóstico físico pediátrico. São Paulo. McGraw-Hill. São Paulo; 2000.

10. Frankenburg WK, Dodds J, Archer P, Shapiro H, Bresnick B. DENVER II: training manual. 2nd ed. Denver, USA: Denver Developmental Materials; 1992.

11. Ribeiro CA, Borba RIH. Crescimento e desenvolvimento da criança. In: Santos L, Silva E. Creche e pré-escola: uma abordagem de saúde. São Paulo: Artes Médicas; 2004.

12. Santos RS, Araújo APQC, Porto MAS. Diagnóstico precoce de anormalidades no desenvolvimento em prematuros: instrumentos de avaliação. J Pediatr (Rio J). 2008;84(4):289-99.

13. Rezende AR, Beteli VC, Santos JLF. Avaliação de habilidades de linguagem e pessoal-sociais pelo Teste de Denver II em instituições de educação infantil. Acta Paul Enferm. 2005;18(1):56-63. 
14. Programa Einstein na Comunidade de Paraisópolis [Internet]. Brasil: Sociedade Beneficente Israelita Brasileira [atualizada 2007; citado 2009 Fev 17]. Disponível em: http://www.einstein.br/portal2007

15. Meisels JS, Wasik BA. Who should be served? Identifying children in need of early intervention. In: Shonkoff JP, Meisels SJ, editors. Handbook of early intervention. Cambridge: Cambridge University Press; 1990. p. 605-32.
16. Sameroff AJ, Seifer R, Barocas R, Zax M, Greenspan S. Intelligence quotient scores of 4-year-old children: social-environmental risk factors. Pediatrics. 1987:79(3):343-50.

17. Andrade CRF. Prevalência das desordens idiopáticas da fala e da linguagem em crianças de um a onze anos de idade. J Public Health.1997;31(5):495501. 